\title{
Effect of Preheating Temperature and Fuel Properties on Combustion and Emission Characteristics of Homogeneous Charge Compression Ignition (HCCI) Engine
}

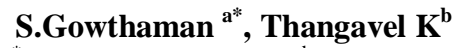 \\ ${ }^{a^{*}}$ Associate Professor, ${ }^{\mathrm{b}}$ PG Student \\ ${ }^{\mathrm{a}, \mathrm{b}}$ Department of Automobile Engineering, \\ ${ }^{\mathrm{a}, \mathrm{b}}$ Kalasalingam Academy of Research and Education, \\ Tamilnadu, India. E-mail: gowthammech@ hotmail.com
}

\begin{abstract}
The homogeneous charge compression ignition (HCCI) engine is the promising technology to reduce the pollutants without affecting its performance and it is also proved by the many studies. This study investigates the performance and emission characteristics of HCCI engine fuelled with diesel - waste cooking oil (WCO) blends and also analysed the effect of air temperature and fuel properties on HCCI engine combustion. The experimental investigation was conducted with single cylinder DI diesel engine and it was slightly modified to port injection system for premixing the charge. The electric air heater was adopted in suction pipe to preheat the inlet air. The experimental investigation conducted in two phases, in the first phase the conventional DI diesel engine was tested with different fuel blends such as B25, B50, B75 and B100 and notes the readings. In the next phase, HCCI engine was operated with same blend ratios. During the experimentation on HCCI engine, the suction air temperature was varied between $40^{\circ} \mathrm{C}$ to $90^{\circ} \mathrm{C}$. From the experimental results, it was found that the HCCI engine has emitted low NOx and smoke emissions at $80^{\circ} \mathrm{C}$ of air temperature for all the blends. Whereas the HCCI engine emitted more carbon monoxide (CO) and hydrocarbon ( $\mathrm{HC}$ ) emissions due to lean mixture causes misfiring in the chamber. In addition, it is also noted that the value of $\mathrm{CO}$ and $\mathrm{HC}$ has been varied with diesel - WCO blends. The specific fuel consumption (SFC) is increased for diesel and biodiesel fuel in HCCI engine compared to compression ignition (CI) engine.
\end{abstract}

Key words: Homogeneous charge compression ignition engine, Waste Cooking oil, Pre injection, Air Preheating, oxides of nitrogen, smoke.

\section{INTRODUCTION}

The Researches on internal combustion (IC) engine and alternative fuels are very important in nowadays due to environmental concern and fossil fuel demand. Particularly, diesel engine are more efficient and it emits harmful pollutants such as carbon dioxide $(\mathrm{CO} 2)$, carbon monoxide (CO), hydrocarbon (HC) and oxides of nitrogen (NOx). These harmful pollutants are creating lot of diseases over the living beings and environment as well. Global warming, acid rain and smog are the serious issues in the recent times, the automobile pollutants play major role in it. In addition to that the automobiles are suffered due to fossil fuel demand and its price, and it will be more in the future due to the vehicle population (1-4). From the past studies, it is proved that biodiesel are suitable replacement for petroleum diesel and it is extracted from waste renewable materials such as seed, waste edible oil and bio-waste. Biodiesel are used directly in a compression ignition engine without modification and it could be utilized as neat oil or blended with fossil fuel. Fortunately, biodiesel are similar properties of petroleum diesel and having $11 \%$ of more oxygen molecule compared to petroleum diesel. The high oxygen molecule accelerates the combustion process and reduced $\mathrm{CO}$ and $\mathrm{HC}$ emissions $(5,6)$. The lower calorific value of biodiesel is generally resulted loss in engine power and increase of fuel consumption (7). The high viscosity and more oxygen content of biodiesel has emitted more NOx emission in CI engine compared to diesel $(8,9)$.

High viscosity of biodiesel needs more time to mix with air and getting vaporized. It causes uneven distribution of fuel in the combustion chamber. The high density rich fuel region creates high NOx and smoke emissions due to the absent of air. The HCCI engine has an ability to eliminate the issues occurred in the CI engine and it can be utilized the biodiesel effectively with low pollutants. The HCCI engines are being actively developed due to its high efficient and ultra-low emissions. The HCCI engine can have the efficiency closer to the conventional diesel engine, with low levels of emissions of NOx and PM. This occurs because the combustion develops with low temperature and burns a premixed air/fuel mixture. On the other hand, $\mathrm{CO}$ and $\mathrm{HC}$ emissions increased due to low temperature combustion process of HCCI engine (10-13).

In reference (14) author used diesel and rapeseed methyl ester in HCCI engine was controlled by exhaust gas re-circulation. The NOx emission was decreased but smoke emission considerably increased due to the recirculation of burnt gas into the combustion chamber. 
The rate of heat release by the engine is decreased by the EGR and it favour for NOx emission reduction, but it increased the rate of smoke emission. Junjum Ma et al. [15] investigated duel fuelled HCCI engine with different premixed ratio using diesel as a primary fuel and n- heptane used secondary fuel. Whereas diesel fuel was injected to in-cylinder and n-heptane was injected through port injector. The author found that NOx emissions were decreased at lower pre mixed ratios and increased at higher pre mixed ratios.

The variations in fuel premixed ratios could not affect the soot formation. From the result, it was identified that the formation $\mathrm{CO}$ emissions were depends on rate of combustion. The $\mathrm{CO}$ emissions were increased with higher pre mixed ratios. So that this study limited the premix fuel ratio to $20 \%$, remaining percentage of fuel will be injected by main injector to start the combustion process. Moteza Faith et al. [16] analysed the effect of exhaust gas recirculation on combustion and emission characteristics of HCCI using n-heptane / natural gas as a fuel. The exhaust gas recirculation was used to control the combustion process and investigated the possibility of controlling the combustion phase and combustion duration. The result shows that the applied EGR have been reduced the charge temperature and leading to retard the start of combustion and prolonged combustion duration. The EGR addition could reduce the heat release rate, improved the fuel economy, reduced the NOx emissions and increased the $\mathrm{CO}$ and $\mathrm{HC}$ emissions.

John abrahim et al. [17] studied combustion characteristics of HCCI engine using n-heptane, methyl decanote and dimethyl ether. Ignition delay and NOx formation rates of three different fuel was investigated. The ignition delay of methyl decanote was shorter than dimethyl ether for all oxygen concentration. In general ignition delay was depends on $\mathrm{O} 2$ concentration in the air-fuel charge. The ignition delay of DME is even shorter than that of methyl decanote addition of NO to simulate EGR effects reduced the ignition delay and NOx emission. Similarly Lu Xingcai et al. used ethanol and n-heptane fuel in HCCI engine, the author conducted the experimental investigation on single cylinder diesel engine with using neat fuel and blend of $10 \%, 20 \%$, $30 \%, 40 \%$ and $50 \%$. He resulted that the HC emissions for n-heptane and blends of 10-30\% fuels have very low, while $\mathrm{HC}$ emission has been increased for $40 \%$ and $50 \%$ of ethanol and n-heptane blends. Because of the blends were gradually increased the ignition delay (18).

Mingfa Yao et al. [19] analysed controlling strategies of dimethyl ether and methanol fuelled HCCI engine, the exhaust gas recirculation was used to control combustion process. The ignition delay and combustion duration could be regulated by the DME percentage and EGR rates. The rate of $\mathrm{HC}$ emissions were depends on DME percentages. The author concluded that the combustion process of HCCI engine could be controlled effectively by the EGR, at the same time it increased the $\mathrm{CO}$ and $\mathrm{HC}$ emissions due to the replacement of oxygen molecules. This study moves forward to control the combustion by suction air temperature and by main injection. This study investigates the performance and emission characteristics of waste cooking oil fuelled HCCI engine and also analyse the effect of air temperature and fuel properties on combustion process.

\section{EXPERIMENTAL SETUP}

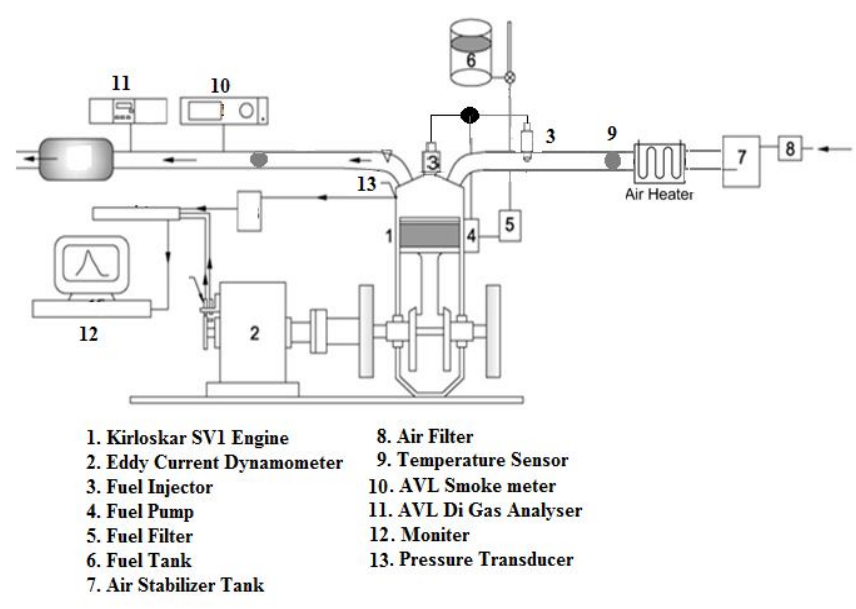

Figure.1 Experimental setup

Table.1 Engine Specifications

\begin{tabular}{|c|c|c|}
\hline SL.N & Parameters & Specification \\
\hline 1. & Make and model & Kirloskar SV1 \\
\hline 2. & General details & $\begin{array}{l}\text { Single cylinder, four } \\
\text { stroke, water cooled, port } \\
\text { injection }\end{array}$ \\
\hline 3. & Bore & $87.5 \mathrm{~mm}$ \\
\hline 4. & Stroke & $110 \mathrm{~mm}$ \\
\hline 5. & Cubic capacity & 0.661 lit \\
\hline 6. & Rated output & $5.9 \mathrm{KW}$ at $1800 \mathrm{rpm}$ \\
\hline 7. & Compression ratio & $17.5: 1$ \\
\hline 8. & $\begin{array}{l}\text { Inlet valve open } \\
\text { BTDC }\end{array}$ & $4.5 \mathrm{deg}$. \\
\hline 9. & $\begin{array}{l}\text { Inlet valve close } \\
\text { ABDC }\end{array}$ & $35.5 \mathrm{deg}$. \\
\hline 10. & $\begin{array}{l}\text { Exhaust valve open } \\
\text { BBDC }\end{array}$ & 35.5 deg. \\
\hline 11. & $\begin{array}{l}\text { Port Fuel injection } \\
\text { timing (BTDC) }\end{array}$ & $10 \mathrm{deg}$. \\
\hline 12. & $\begin{array}{l}\text { Direct fuel injection } \\
\text { Timing(ATDC) }\end{array}$ & $10 \mathrm{deg}$ \\
\hline
\end{tabular}


The experimental study was carried out on single cylinder, four stroke, water cooled and DI diesel engine. The DI diesel engine was modified to HCCI mode engine for conducting the test by adopting port and DI injection systems. The port injector was used to premix the $20 \%$ of fuel for ensuring the fuel present in the entire area of the combustion chamber. The injection timing of the port injector was fixed as $5.4^{\circ}$ BTDC. The figure 1 shows the experiment set up of HCCI engine and specifications are listed in table 1 . The electric heater was fixed at inlet pipe of the engine to vaporise the mixture to nearly homogenous condition. The complete process will be done by the engine control system. It is also ensure that the port injector injects $20 \%$ of fuel for different load conditions. During the experimentation, the tests were conducted with different engine loads at constant engine speed of $1800 \mathrm{rpm}$. The engine is coupled with eddy current dynamometer for varying the load. The load and speed of the engine is ensured by the digital indicator placed in the control panel. The test engine is equipped with water cooling system and temperatures of inlet temperature and outlet water temperature are being measured by thermocouple. These readings are displayed in digital meter on the control panel. The AVL five-gas analyser was used to measure the exhaust emission from the HCCI mode engine such as $\mathrm{CO}, \mathrm{HC}, \mathrm{NOx}, \mathrm{CO} 2$ and $\mathrm{O} 2$. The exhaust smoke was measured by AVL smoke meter.

Table 2. Properties of test fuels

\begin{tabular}{|l|l|l|l|}
\hline \multicolumn{1}{|c|}{ Properties } & \multicolumn{1}{|c|}{ B100 } & \multicolumn{1}{|c|}{ B50 } & \multicolumn{1}{c|}{ Diesel } \\
\hline $\begin{array}{l}\text { Density @ } 15^{\circ} \mathrm{C} \\
\left(\mathrm{kg} / \mathrm{m}^{3}\right)\end{array}$ & $\mathbf{9 3 8}$ & $\mathbf{8 8 3}$ & $\mathbf{8 3 1}$ \\
\hline $\begin{array}{l}\text { Kinematic viscosity @ } \\
40^{\circ} \mathrm{C}(\mathrm{cSt})\end{array}$ & $\mathbf{9 . 7 1}$ & $\mathbf{6 . 5 9}$ & $\mathbf{3 . 2 1}$ \\
\hline Specific gravity & $\mathbf{0 . 9 3 3}$ & $\mathbf{0 . 8 9 3}$ & $\mathbf{0 . 8 6 3}$ \\
\hline Calorific value $(\mathrm{kj} / \mathrm{kg})$ & $\mathbf{3 6 , 7 5 0}$ & $\mathbf{3 9 , 3 6 0}$ & $\mathbf{4 4 , 2 3 2}$ \\
\hline Flash point $\left({ }^{\circ} \mathrm{C}\right)$ & $\mathbf{1 3 4}$ & $\mathbf{1 2 5}$ & $\mathbf{6 6}$ \\
\hline Cloud point $(\mathrm{C})$ & $\mathbf{- 3}$ & $\mathbf{- 6}$ & $\mathbf{7 3}$ \\
\hline Pour point $\left({ }^{\circ} \mathrm{C}\right)$ & $\mathbf{- 4}$ & $\mathbf{- 8}$ to -12 & $\mathbf{- 1 7}$ \\
\hline $\begin{array}{l}\text { Acid number }(\mathrm{mg} \\
\text { KOH/g) }\end{array}$ & $\mathbf{0 . 7 2}$ & $\mathbf{0 . 6 6}$ & $\mathbf{0 . 2}$ \\
\hline \%C (wt) & $\mathbf{7 6}$ & $\mathbf{8 0}$ & $\mathbf{8 6 . 7}$ \\
\hline \% H (wt) & $\mathbf{1 1 . 8 1}$ & $\mathbf{1 1 . 8 3}$ & $\mathbf{1 2 . 8}$ \\
\hline \% O (wt) & $\mathbf{1 1 . 3 2}$ & $\mathbf{7 . 3 6}$ & $\mathbf{-}$ \\
\hline ppm of S (wt) & $\mathbf{1 2}$ & $\mathbf{8 . 2 2}$ & $\mathbf{3 4 0}$ \\
\hline Cetane number & $\mathbf{5 3}$ & $\mathbf{4 9}$ & $\mathbf{4 9 . 1 4}$ \\
\hline
\end{tabular}

\section{EXPERIMENTAL PROCEDURE}

Initially the engine was operated with no load condition, since to achieve the saturated engine temperature. The experimental study was carried out into two phases. In the first phase, the engine was operated as conventional CI mode with using diesel, biodiesel and blends. The performance and emission values were observed. In the second, the experimental investigations have been carried on HCCI engine operated with diesel, biodiesel and blends. The same test will be continued to operate the HCCI engine with different inlet charge temperature between $40^{\circ} \mathrm{C}$ to $90^{\circ} \mathrm{C}$. The performance and emission values were noted for all the conditions.
The whole testes were followed with the engine speed of $1800 \mathrm{rpm}$. The noted results were analysed and compared to conventional CI engine. The biodiesel has more viscosity and higher auto ignition temperature than reference diesel as listed in table 2. So The HCCI engine has initially started as DI mode engine that is biodiesel is directly injected on the combustion chamber and switch over the DI injector into port fuel injection. The fuel injection timing is totally controlled by ECU depends on the load and speed of the engine. The speed sensor or optical sensor is adopted near the engine crank shaft used to identify the engine speed and position of piston inside the cylinder. The output of the sensor is feed to the ECU, depends on the signal the ECU can change the fuel injection time and injection duration.

\section{RESULT AND DISCUSSION}

\subsection{PERFORMANCE CHARACTERISTICS}

The conventional diesel engine has lower specific fuel consumption (SFC) rate compared to HCCI engine. The reason for this is the $\mathrm{CI}$ engine operates with heterogeneous mode of combustion, where the fuels are accumulated near to the fuel injector and there is an absent of fuel near to the cylinder wall. The accumulated fuel start to combust at end of the compression process and generated more heat power to drive the engine. It is also noted that the value of SFC is increased with the addition of WCO due to its low calorific value. The figure. 2 shows the variation in SFC for diesel, biodiesel and B50 fuelled CI and HCCI engine. From the result, it is observed that the HCCI engine has higher SFC rate compared to traditional CI engine. It may be due to low combustion temperature and poor volumetric efficiency of HCCI engine. The preheating of air in HCCI engine has reduced the volumetric efficiency and it directly affects the rate of combustion. It is also reflected in the test result, the values of SFC is increased with the preheating temperature. At $80^{\circ} \mathrm{C}$ preheating temperature, the HCCI engine operates efficiently with low SFC for all loads compared to other preheating temperatures. Hence it is taken as reference temperature for all other fuels used in HCCI engine and analyse its performance and emission characteristics with $80^{\circ} \mathrm{C}$ preheating temperature. The figure 2 compares the SFC values with brake power (BP) generated by the engine.

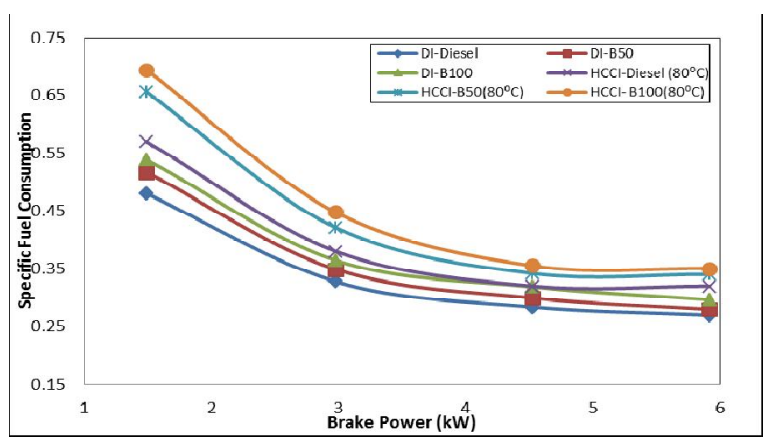

Figure 2. Variation in SFC with Brake Power 
The figure 2 is clearly shows that the HCCI engine has consumed more fuel compared to $\mathrm{CI}$ engine. It may be happened due to lean combustion of HCCI and it also reduced peak combustion temperature and heat release rate. To prevent the power loss the HCCI engine consumes more fuel to compensate the power requirements. From the figure 2 , it is observed that the value of SFC for diesel, biodiesel and B50 operated HCCI engine is much higher than conventional CI engine. The WCO fuelled both CI and HCCI engines has resulted higher SFC than the diesel and B50. Because, the neat WCO have lower calorific value compared to other fuels.

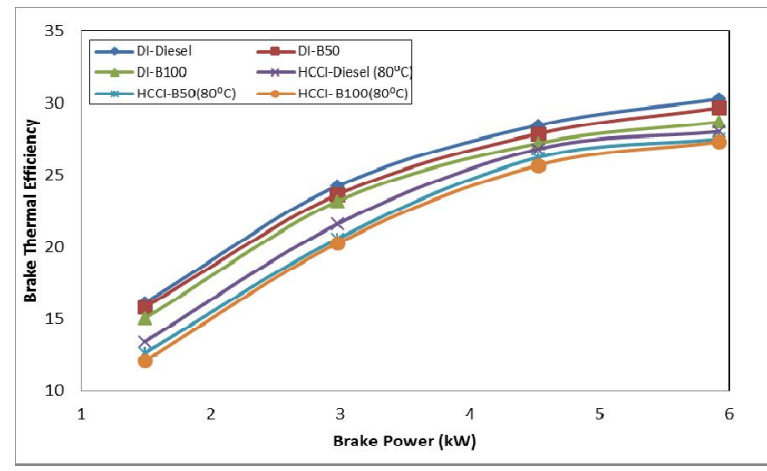

Figure 3. Variation in BTE with Brake Power

The brake thermal efficiency (BTE) is indicated that the percentages of fuel converted into useful work. The BTE of both CI and HCCI engine with different conditions are shown figure 3. The HCCI engine has lower brake thermal efficiency compared to CI engine and it is also varied with air preheating temperature and fuel properties. The diesel fuelled HCCI engine has higher BTE compared to other blends such as B25, B50, B75 and B100. It might be happened due to the properties of diesel fuel, it has higher calorific value, low viscosity and easy get vaporized at minimum temperature. The BTE of HCCI engine is decreased with the addition of WCO to diesel fuel. The HCCI engine with $\mathrm{B} 50$ and B100 has registered low BTE for all load conditions. For the reason that the WCO is much higher in viscosity and lower calorific value compared to diesel. In addition, it might be happened due to premixing of high viscus fuel like WCO. That is during the engine operation $20 \%$ of premixed WCO enters into the chamber and well mixed with air to form as too lean mixture. After that at end of the compression process, the remaining amount of fuel will be injected by the main injector to start the combustion process. For the moment in the combustion chamber having too lean mixture at nearer to the cylinder wall. These lean mixtures have misfired at different places with different ignition timing in the combustion chamber. This uneven combustion reduced the engine power and combustion temperature.

\subsection{EMISSIONS CHARACTERISTICS}

In general, the smoke emission indicates the percentage of complete combustion occurred in the combustion process. The HCCI engine has lower smoke emission compared to conventional diesel engine due to the following reasons. The premixing of fuel in HCCI engine eliminates rich fuel region and preheated air makes the change to homogeneous or nearly homogenous state before taking the combustion process. These factors are favouring to have complete combustion in HCCI engine and reduced the smoke emission drastically. The figure 4 shows the variation in smoke emissions for diesel, biodiesel and B50 fuelled CI and HCCI engine. From the figure 4, it is noted that the HCCI engine has emitted low smoke emissions compared to CI engine for all loading conditions. When compared with diesel, the waste cooking oil fuelled HCCI engine has emitted low smoke emission.

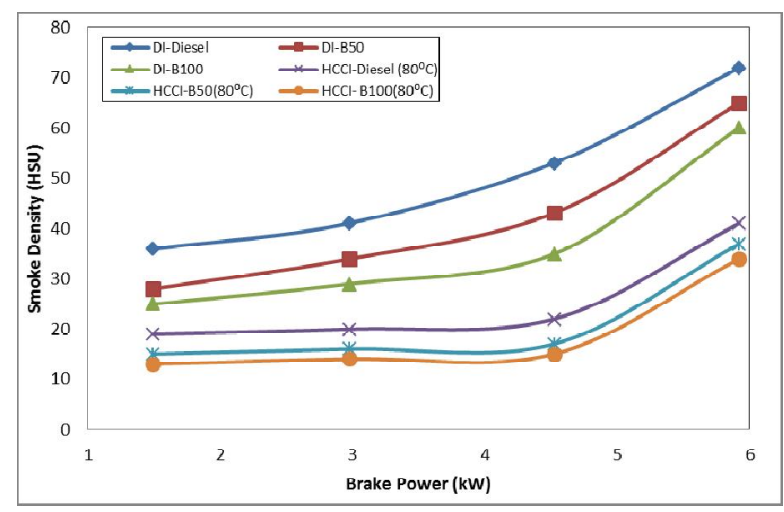

Figure 4. Variation in Smoke Density with Brake Power

The properties like high cetane number and more oxygen molecules of WCO help to accelerate the combustion and reduced the smoke density. The neat WCO fuelled HCCI registered low smoke emission than diesel and B50. The main reason for smoke formation is incomplete combustion or absents of oxygen molecule in the chamber. Fortunately biodiesel has $11 \%$ of oxygen molecules and it is improving combustion efficiency and reduced smoke emission. The reductions in smoke density are $12 \%, 22 \%$ and $18 \%$ for diesel, B50 and B100 respectively.

The HCCI engine operates with lean air fuel charge

for all loading conditions and it reduced the overall combustion temperature. Lean mixture and low combustion temperature of HCCI engine reduced formation oxides of nitrogen (NOx) in the form of $\mathrm{NO} 2$ and NO. The reason for NOx formation in CI engine is due to high combustion temperature, the rich fuel region in CI engine has created more heat energy and it favours for thermal NOx formation. In addition to that the rich fuel region has more fuel molecules, each molecules contain number of nitrogen atoms. These nitrogen reacts with its own oxygen at higher temperature and liberate more NOx emissions. The figure 5 shows the variation in NOx emissions emitted for diesel, neat WCO and B50 fuelled CI and HCCI engine with different percentage of load. 
In this study, the HCCI engine was allowed to operate with diesel, WCO and B50 fuels and investigation being continued to operate the engine with different inlet air temperature such as $60^{\circ} \mathrm{C}, 70^{\circ} \mathrm{C}, 80^{\circ} \mathrm{C}$ and $90^{\circ} \mathrm{C}$. The result indicates that $80^{\circ} \mathrm{C}$ air temperature operated HCCI engine has emitted low NOx emissions even using diesel, biodiesel and B50 as a fuel. The diesel fuelled HCCI engine has the maximum value of NOx emission about 510ppm, and 486ppm and 410ppm for $\mathrm{B} 50$ and $\mathrm{WCO}$ fuelled engine. The rate of reduction in NOx emissions are about $24 \%, 36 \%$ and $42 \%$ for diesel, $\mathrm{B} 50$ and biodiesel operated HCCI engine.

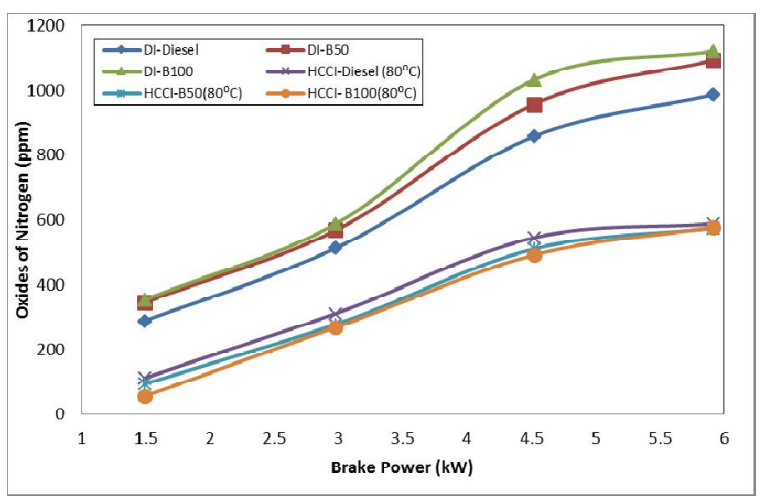

Figure 5. Variation in NOx with Brake Power

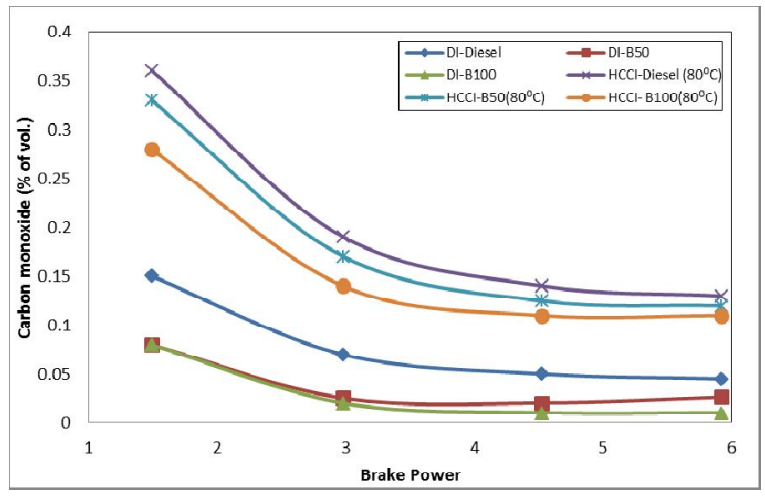

Figure 6. Variation in $\mathrm{CO}$ with Brake Power

Figure 6 shows the variations in carbon monoxide (CO) for diesel, WCO and blend B50 in CI and HCCI engine. The HCCI engine has emitted high $\mathrm{CO}$ emission for both the fuel due to lean air- fuel charge. The higher $\mathrm{CO}$ emission is the one of the disadvantage of HCCI engine, which could be controlled by increasing the preheating temperature. The figure 6 shows that diesel, WCO and B50 fuelled HCCI engine has higher CO emission than $\mathrm{CI}$ engine. At the same time waste cooking oil fuelled HCCI engine has low $\mathrm{CO}$ emissions than the diesel and B50 fuels. Because, biodiesel has more oxygen molecules than the diesel and its lead to oxygenated $\mathrm{CO}$ molecules into $\mathrm{CO} 2$. It is also resulted $80^{\circ} \mathrm{C}$ air temperature operated $\mathrm{HCCI}$ engine has low $\mathrm{CO}$ emissions compared to other air temperature operated engine. If increasing the air temperature more than $80^{\circ} \mathrm{C}$, it further increased the $\mathrm{CO}$ emission due to poor volumetric efficiency. The higher inlet air temperature leads to misfire, the charge have started to ignite earlier that the piston reaches TDC position. It may also be the reason for high $\mathrm{CO}$ emission in HCCI engine at higher preheating temperature.

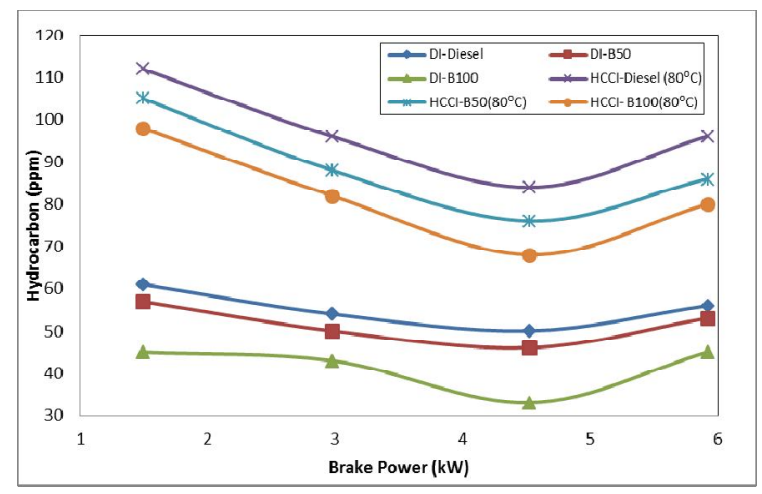

Figure 7. Variation in $\mathrm{HC}$ with Brake Power

Figure 7 shows variation in hydrocarbon emission for diesel, WCO and B50 fuelled CI and HCCI engine. The reasons for $\mathrm{HC}$ formation are low cetane number of fuel, misfire of charge and fuel quenching. The HCCI engine has emitted high $\mathrm{HC}$ emission compared to $\mathrm{CI}$ engine. In HCCI engine the combustion process is started after the injection from main injector and the ignition is taken place at multiple location in the chamber. Due to the premixing of fuel in HCCI engine, the different ratio of charge is accumulated inside the chamber, such as some portion have rich charge and some other portion have lean charge. During the combustion the rich fuel region starts to ignite and then lean charge started to ignite. The lean air-fuel charge was partially burn and leaving from the chamber during the exhaust stroke. These unburned partials are known as hydrocarbon emission.

From the figure 7 , it is observed that the compression ignition engine has emitted low $\mathrm{HC}$ emissions while using diesel, WCO and B50 fuels compared to HCCI engine. The WCO and B50 fuelled both $\mathrm{CI}$ and HCCI engines have lower HC emissions than the diesel fuel. The reason is WCO has high cetane number compared to petroleum diesel and it favours to take the ignition more faster even at low chamber temperature. The $80^{\circ} \mathrm{C}$ preheated HCCI engine has lower $\mathrm{HC}$ emission than the other preheated temperatures. The preheating of air in HCCI engine is the most important to create the homogeneous or partially homogenous mixture. The quality of the mixture is purely depended on preheating of air.

\subsection{COMBUSTION CHARACTERISTICS}

The variations in cylinder pressure with crank angle for diesel, WCO and B50 fuelled CI and HCCI engine are shown in figure 8 . The HCCI engine has low peak pressure compared to $\mathrm{CI}$ engine due to lean combustion. 
The premixed and lean charge of HCCI engine has extend the ignition delay and reduced the in-cylinder temperature. From the figure 8, it is noted that the HCCI engine has longer ignition compared to CI engine. The reason is, due to the premixed fuel and absents of rich fuel region in the HCCI engine has delayed the start of combustion after the main injection. It is also noticed that the HCCI engine has longer combustion duration compared to $\mathrm{CI}$ engine. Because the HCCI engine using premixed fuel and it spread entire area of the chamber before starting the combustion. At end of the compression process, the combustion has started at multiple points in the cylinder. The start of combustion and combustion during are varied based on the fuel and preheating temperature.

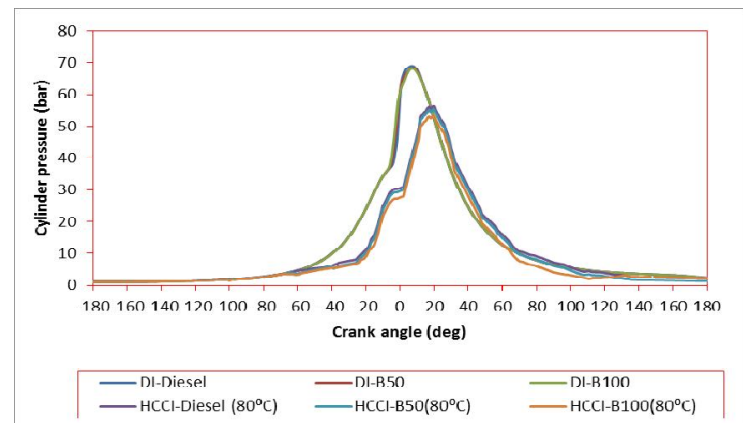

Figure 8. Variation in Cylinder pressure with crank angle

From the figure 8 , it is also found that the HCCI engine has two stage of combustion, the first stage of combustion has been started nearer to the TDC position at -10deg and the second stage started after TDC at $10 \mathrm{deg}$. The second stage of combustion is dependent on ignition of first stage. This study resulted that the diesel fuelled HCCI engine has high peak cylinder pressure of 58 bar compared to B50 and WCO fuelled engine.

The figure. 9 shows heat release rate of diesel, WCO and B50 fuelled CI and HCCI engine. The diesel fuelled $\mathrm{CI}$ engine has high heat release rate than the other fuels and the ignition is started at 50deg BTDC. The maximum heat release rate for diesel fuelled CI engine is $116 \mathrm{kj} / \mathrm{m} 3 \mathrm{deg}$. From the figure 9 , it is observed that the combustion of HCCI engine is started at after TDC for diesel, WCO and B50 fuelled. The diesel fuelled $80^{\circ} \mathrm{C}$ air temperature operated $\mathrm{HCCI}$ engine has maximum heat release rate value of $82 \mathrm{kj} / \mathrm{m} 3 \mathrm{deg}$.

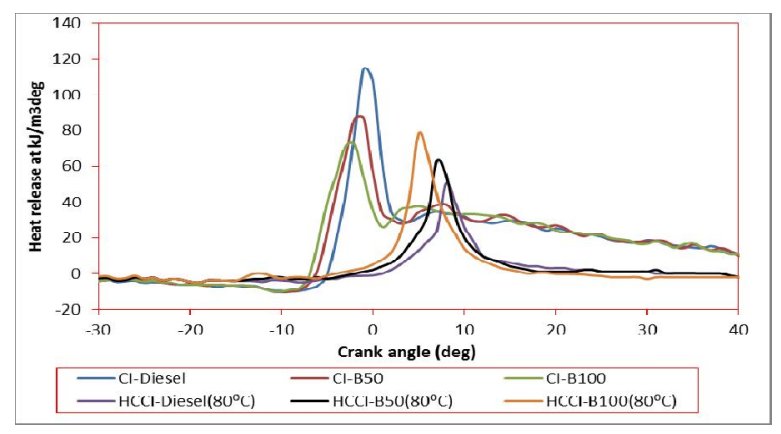

Figure 9. Variation in Heat Release rate with crank angle

\section{CONCLUSION}

From this study, it is concluded that the HCCI engine is the suitable replacement for conventional CI engine and it can be operated efficiently with different fuels like diesel, biodiesel and their blends. In this study, the combustion process of HCCI engine

From this research, identified the optimum inlet air temperature for diesel, biodiesel and B50 fuelled HCCI engine is $80^{\circ} \mathrm{C}$. The HCCI engine has low power output and having low smoke and NOx emission while engine operated by $80^{\circ} \mathrm{C}$ inlet air temperature. The specific fuel consumed by the HCCI engine is much higher than compression ignition engine for all fuels; $80^{\circ} \mathrm{C}$ air temperature operated engine has low SFC than others. The diesel fuelled HCCI engine has low SFC values compared to B50 and biodiesel operated HCCI engine.

The brake thermal efficiency of $80^{\circ} \mathrm{C}$ temperature operated HCCI engine is much higher compared to other inlet air temperatures. The power output of diesel fuelled HCCI engine was higher than B50 and biodiesel fuelled engine. At $75 \%$ load HCCI engine had higher value of BTE compared to other load. The value of smoke density from the biodiesel fuelled HCCI engine was lower than diesel and $\mathrm{B} 50$ fuelled $80^{\circ} \mathrm{C}$ inlet air temperature operated HCCI engine.

From the result, it was concluded that the HCCI engine has lower NOx emission for all operating conditions compared to $\mathrm{CI}$ engine. The $80^{\circ} \mathrm{C}$ operated HCCI engine has lower NOx emissions than other air temperature operated engine. The biodiesel fuelled HCCI engine has emitted low NOx emissions compared to diesel and B50 fuelled HCCI engine. The emissions of $\mathrm{CO}$ and $\mathrm{HC}$ were reduced with increasing the air temperature. The HCCI engine had decreased the CO emission with increasing the load on the engine. The $80^{\circ} \mathrm{C}$ air temperature biodiesel operated HCCI engine had lower $\mathrm{CO}$ emissions when compared to other fuels. $\mathrm{HC}$ emissions from the HCCI engine were high than the compression ignition engine. The biodiesel fuelled 80C air temperature operated engine has lower HC emissions compared to diesel and B50 fuelled engine.

The HCCI engine has low in-cylinder pressure and heat release rate compared to compression ignition engine. This study resulted HCCI has two stage of combustion process and the start of ignition timing is depend on properties of fuel used in HCCI engine. the biodiesel fuelled $80^{\circ} \mathrm{C}$ air temperature operated HCCI engine has high cylinder pressure and heat release rate. The biodiesel fuelled HCCI engine has earlier start of combustion process than the other fuel and it have shorter in ignition delay. 


\section{REFERENCES}

1. Czerwinski J. "Performance of HD-DI diesel engine with addition of ethanol and rapeseed oil. Transactions of Society of Automotive Engineering, 1994; 940545.

2. Senthil Kumar M, Ramesh A, Nagalingam B. Use of hydrogen to enhance the performance of a vegetable oil fuelled compression ignition engine. International Journal of Hydrogen Energy 2003; 28(10):1143-54.

3. Humke AL, Barsic NJ. "Performance and emission characteristics of a naturally aspirated diesel engine with vegetable oils (Part-2). Transactions of Society of Automotive Engineers 1981; 810955.

4. Senthil Kumar M, Ramesh A, Nagalingam B. "An experimental comparison of methods to use methanol and Jatropha oil in a compression ignition engine". Biomass Bioenergy 2003;25(3):309-18.

5. Muniyappa PR, Brammer SC, Noureddini H. "Improved conversion of plant oils and animal fats into biodiesel and co-product". Journal of Bioresoure Technology 1996; 56(1):19-24.

6. Tashtoush GM, Al-Widyan MI, Al-Jarrah MM. "Experimental study on evaluation and optimization of conversion of waste animal fat into biodiesel". Journal of Energy Conversion Management 2004. In Press, Corrected Proof.

7. Demirbas and S. Karslioglu, "Biodiesel production from vegetable oils and Animal Fat oil", Journal of energy sources, Part - A, 29:133-141, 2007.

8. Yamasaki Y, Iida N. Numerical analysis of auto ignition and combustion of n-butane and air mixture in the homogeneous charge compression ignition engine by using elementary reactions. SAE paper 2003-01-1090; 2003.

9. S Gowthaman, AP Sathiyagnanam, Performance and emission characteristics of homogeneous charge compression ignition engine-a review, International Journal of Ambient Energy 38 (7), 672-684

10. Lu Xingcai,Hou Yuchun,Zu Linlin,Huang Zhen. Experimental study on the auto-ignition and combustion characteristics in the homogeneous charge compression ignition(HCCI)combustion operation with ethanol/nheptane blend fuels by port injection;2006:vol.5.p.262231.

11. S Gowthaman, AP Sathiyagnanam, Analysis the optimum inlet air temperature for controlling homogeneous charge compression ignition (HCCI) engine, Alexandria engineering journal, 2017
12. S Gowthaman, AP Sathiyagnanam, Effects of charge temperature and fuel injection pressure on HCCI engine, Alexandria Engineering Journal 55 (1), 119-125

13. Christensen M, Hultqvist A, johansson B, Demonstrating the multi - fuel capacity of a homogeneous charge compression ignition engine with variable compression ratios. SAE 1999-01-3679;1999.

14. Hatim Machrafi, Simeon Cavadias, Jacques Amouroux. A parametric study on the emissions from an HCCI alternative combustion engine resulting from the auto ignition of primary reference fuels. Applied Energy 85 (2008) 755-764.

15. Junjum Ma, Xingcai Lu, Libin Ji, Zhen Huang. An experimental study of HCCI-DI combustion and emissions in a diesel engine with dual fuel. international journal of thermal science 47 (2008) 1235-1242.

16. Morteza Faith, R Khoshbakhrti Saray, M David Checkel. The influence of exhaust gas recirculation (EGR) on combustion and emissions of n-heptane/ natural gas fuelled HCCI engine. Applied Energy (2011).

17. John Abraham, Seth R. Hoffman. A comparative study of n-heptane, methyl decanate, and dimethyl ether combustion characteristics under HCCI engine conditions. Fuel 88 (2009) 1199-1108.

18. Lu Xingcai, Hou Yuchun, Zu Linlin, Huang zhen. Experimental study on the auto- ignition and combustion characteristics in the HCCI combustion operation with ethanol/ n-heptane blend fuels by port injection. fuel 85 (2006) 2622- 2631.

19. Mingfa Yao, Zheng Chen, Zunqing Zheng, Bo Zhang, Yuan Xing. Study onthe controlling strategies of HCCI combustion with fuel of dimethyl ether and methanol. Fuel 85 (2006) 2046-2056. 